\title{
Exercise Training for Patients After Coronary Artery Bypass Grafting Surgery
}

\author{
Ching Lan, Ssu-Yuan Chen and Jin-Shin Lai \\ Department of Physical Medicine and Rehabilitation, National Taiwan University \\ Hospital, and National Taiwan University, College of Medicine, Taipei, \\ Taiwan
}

\section{Introduction}

Patients with coronary artery disease (CAD) who suffer persistent symptoms and reduced quality of life while receiving medical therapy are considered for revascularization. ${ }^{1}$ Coronary artery bypass grafting (CABG) and percutaneous coronary intervention (PCI) are the most common methods of revascularization for symptomatic CAD. These two interventions can reduce ischemic symptoms such as angina or dyspnea, ${ }^{2}$ thus improving the ability to undertake physical training. Shorter length of hospitalization, ${ }^{3}$ earlier return to work, ${ }^{4}$ and better life adaptation ${ }^{5}$ were reported in patients undergoing PCI. However, the incidence rate of restenosis following PCI is higher than $\mathrm{CABG}^{6}{ }^{6}$ and PCI patients who required further interventions outnumbered the patients who underwent CABG.7-8 A recent meta-analysis study found that the mortality rate and the rate of revascularization were significantly lower in the CABG group than the PCI group $(9.9 \%$ vs $24.5 \%) .{ }^{9}$ In a subgroup analysis, the 5-year mortality rate of DM patients was also lower in the CABG group.

In the era of drug-eluting stent (DES), the Synergy between PCI with Taxus and Cardiac Surgery (SYNTAX) trial ${ }^{10}$ found that major adverse cardiovascular events rates at 12 months were significantly higher in the PCI group $(17.8 \%$ vs $12.4 \%)$, and the rate of revascularization was lower in the CABG group $(5.9 \%$ vs $13.5 \%)$, but stroke was significantly higher in the CABG group $(2.2 \%$ vs $0.6 \%)$. However, the application of new surgical technique, such as off-pump CABG (OPCAB) may reduce the rate of stroke after surgery. In general, CABG remains the method of choice in patients with left main disease, multivessel disease, especially in diabetic patients, or patients with left ventricular dysfunction, in the event of failure of $\mathrm{PCI}$, and in-stent restenosis. ${ }^{11}$ Although the procedure risk is higher for patients receiving $C A B G$, the extent of revascularization is more complete, ${ }^{12}$ and hence the potential of training is higher than patients with PCI. The objective of this study is to review the effect of exercise training program in patients with CABG.

\section{Principle of exercise training}

Exercise is a major component for patients with CAD. Cardiac rehabilitation (CR) usually beginning during hospitalization (phase I, inpatient), followed by a supervised outpatient program lasting 3-6 months (phase II), and continuing in a lifetime 
maintenance stage in minimally supervised or unsupervised setting (phase III). According to the recommendations of American College of Sports Medicine, ${ }^{13}$ patients with CABG should perform aerobic exercise 3-5 times per week and 20-60 minutes for

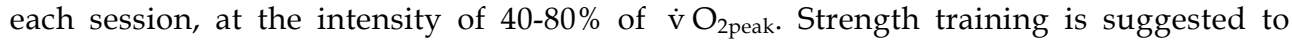
perform 2-3 times per week at the intensity of 40-50\% of maximal voluntary contraction with $10-15$ repetitions.

For the coronary patients, exercises with moderate intensity have been shown to improve functional capacity, and it may provide greater safety during unsupervised training. Lower intensity exercise training also increases the acceptance of exercise program, particularly unfit and elderly patients. Therefore, some oriental conditioning exercises deserve more attention because they are less intense, easily accessible, low cost and therefore suitable for implementation in the community.

\section{Benefits of exercise training}

\subsection{Cardiorespiratory fitness}

Cardiac rehabilitation exercise training improves exercise capacity, without significant complications or other adverse effects. Peak oxygen uptake is the best indicator for cardiorespiratory fitness, and attaining a high $\dot{\mathrm{v}} \mathrm{O}_{2 \text { peak }}$ requires integration of high levels of pulmonary, cardiovascular and neuromuscular function. In patient with CAD, the level of $\dot{\mathrm{v}} \mathrm{O}_{2 \text { peak }}$ is also a good predictor for mortality rate. Kavanagh et al. ${ }^{14}$ reported exercise test data for 12,169 male rehabilitation candidates, and found the most powerful predictor of cardiac and all-cause mortality was $\dot{\mathrm{v}} \mathrm{O}_{2 \text { peak. }}$ Values of $<15,15$ to 22 , and $>22 \mathrm{~mL} \mathrm{~kg}^{-1} \mathrm{~min}^{-1}$ yielded respective hazard ratios of 1.00, 0.62 , and 0.39 for cardiac deaths and 1.00, 0.66, and 0.45 for all-cause deaths. Additionally, the mortality rate might decrease $9 \%$ for each 1 $\mathrm{mL} \mathrm{kg}^{-1} \mathrm{~min}^{-1}$ increase of $\dot{\mathrm{v}} \mathrm{O}_{2 \text { peak. }}{ }^{14}$ For patients with $\mathrm{CABG}$, previous studies reported $10.5 \%-48.2 \%$ increase of $\dot{\mathrm{v}} \mathrm{O}_{2 \text { peak }}$ in outpatient $\mathrm{CR}$, and the increase of absolute value was 1.9-6.6 $\mathrm{mL}^{\mathrm{kg}}^{-1} \mathrm{~min}^{-1}$ (Table 1), ${ }^{15-32}$ depended on different exercise protocol and the initial level of fitness.

\begin{tabular}{|c|c|c|c|}
\hline Study & Patients & Intervention & Outcomes \\
\hline $\begin{array}{l}\text { Haennel et } \mathrm{al}^{15} \\
(1991)\end{array}$ & $\begin{array}{l}24 \text { men } \\
\text { 9-10 wk after CABG }\end{array}$ & $\begin{array}{l}\text { Cycle training }(\mathrm{n}=8) \text { : cycling } \\
24 \text { min, } 3 \text { times } / \mathrm{wk} \text { for } 8 \mathrm{wk} \\
\text { Hydraulic circuit training } \\
(\mathrm{HCT}, \mathrm{n}=8): 24 \text { min circuit } \\
\text { training } 3 \text { times } / \mathrm{wk} \text { for } 8 \mathrm{wk} \\
\text { Control }(\mathrm{n}=8)\end{array}$ & $\begin{array}{l}\dot{\mathrm{v}} \mathrm{O}_{2 \text { peak }} \text { between baseline and } 8 \\
\text { wk: } \\
\text { Cycling: } 21.4 \text { vs } 25.7 \mathrm{~mL} \cdot \mathrm{kg}^{-1} \mathrm{~min}^{-1} \\
(20.1 \%) \\
\text { HCT: } 21.2 \text { vs } 23.6 \mathrm{~mL} \cdot \mathrm{kg}^{-1} \mathrm{~min}^{-1} \\
(11.3 \%) \\
\text { Cardiac output between baseline } \\
\text { and } 8 \text { wk: } \\
\text { Cycling: } 14.3 \text { vs } 16.8 \mathrm{~L} \mathrm{~min}^{-1} \\
(17.5 \%) \\
\text { HCT: } 13.1 \text { vs } 15.1 \mathrm{~L} \cdot \mathrm{min}^{-1} \\
(15.3 \%)\end{array}$ \\
\hline $\begin{array}{l}\text { Engblom et } \text { al }^{16} \\
\text { (1992) }\end{array}$ & $\begin{array}{l}171 \text { men } \\
2 \text { mon after } C A B G\end{array}$ & $\begin{array}{l}\text { Rehabilitation group }(n=93) \\
\text { 3- wk exercise followed by } \\
\text { 2-day refresher for } 8 \mathrm{~m} \\
\text { Reference group }(n=78)\end{array}$ & $\begin{array}{l}\text { Maximal work load increased in } \\
\text { both groups, but the increase is } \\
\text { greater in rehabilitation group } \\
\text { than in reference group } 12 \text { months } \\
\text { post-operatively. }\end{array}$ \\
\hline
\end{tabular}




\begin{tabular}{|c|c|c|c|}
\hline Study & Patients & Intervention & Outcomes \\
\hline $\begin{array}{l}\text { Dubach et al }{ }^{17} \\
\text { (1995) }\end{array}$ & $\begin{array}{l}42 \text { men } \\
1 \text { mon after } C A B G\end{array}$ & $\begin{array}{l}\text { Exercise group }(\mathrm{n}=22) \text { : } \\
\text { walking } 1 \mathrm{~h} \text { twice daily for } 1 \\
\mathrm{~m} \text {, followed by } 1 \mathrm{~m} \text { of usual } \\
\text { care } \\
\text { Control group }(\mathrm{n}=20) \text { : usual } \\
\text { care for } 1 \mathrm{~m} \text {, followed by } \\
\text { walking } 1 \mathrm{~h} \text { twice daily for } \\
1 \mathrm{~m}\end{array}$ & $\begin{array}{l}\dot{\mathrm{v}} \mathrm{O}_{2 \text { peak }} \text { between baseline and } 1 \\
\text { mon: } \\
\text { Ex: } 22.6 \text { vs } 24.5 \mathrm{~mL} \mathrm{~kg}^{-1} \mathrm{~min}^{-1} \\
(8.4 \%) \\
\text { Control: } 21.0 \text { vs } 23.7 \mathrm{~mL} \mathrm{~kg}^{-1} \mathrm{~min}^{-1} \\
(12.9 \%) \\
\dot{\mathrm{v}} \mathrm{O}_{2 \text { peak }} \text { between } 1 \mathrm{mon} \text { and } 2 \\
\text { mon: } \\
\text { Ex: } 24.5 \text { vs } 26.4 \mathrm{~mL} \cdot \mathrm{kg}^{-1} \mathrm{~min}^{-1} \\
(7.8 \%) \\
\text { Control: } 23.7 \mathrm{vs} 25.0 \mathrm{~mL} \mathrm{~kg}^{-1} \mathrm{~min}^{-1} \\
(5.5 \%)\end{array}$ \\
\hline $\begin{array}{l}\text { Daida et al }{ }^{18} \\
(1996)\end{array}$ & $\begin{array}{l}15 \mathrm{M}, 2 \mathrm{~F} \\
53 \pm 3 \mathrm{y} / \mathrm{o}, 3 \mathrm{~m} \text { after } \\
\text { CABG }\end{array}$ & $\begin{array}{l}6-8 \text { wk aerobic training, } \\
3 \text { times/wk, } 40 \text { min each } \\
\text { time, } \\
\text { at } \mathrm{RPE} 12-13\end{array}$ & $\begin{array}{l}\dot{\mathrm{V}} \mathrm{O}_{2 \text { peak }} \text { between baseline and } 9 \\
\text { mon: } \\
21.9 \text { vs } 27.4 \mathrm{~mL} \mathrm{~kg}^{-1} \mathrm{~min}^{-1}(25.1 \%) \\
\uparrow \text { Exercise time, } \mathrm{O} 2 \text { pulse, peak HR }\end{array}$ \\
\hline $\begin{array}{l}\text { Mariorana et al }{ }^{19} \\
\text { (1997) }\end{array}$ & $\begin{array}{l}26 \text { Men } \\
60 \pm 8.5 \mathrm{y} / \mathrm{o}, \\
18 \text { mon after CABG }\end{array}$ & $\begin{array}{l}\text { Circuit weight training } \\
\text { group, }(\text { CWT, } n=12): 10 \text { wks } \\
\text { CWT at } 40-60 \% \text { max. } \\
\text { contraction } \\
\text { Control group }(n=14)\end{array}$ & $\begin{array}{l}\text { Strength increased by } 18 \% \text { in five } \\
\text { out of seven exercise in the CWT } \\
\text { group, but unchanged in the } \\
\text { control group } \\
\dot{\mathrm{V}} \mathrm{O}_{2 \text { peak }} \text { : no increase in both } \\
\text { groups }\end{array}$ \\
\hline $\begin{array}{l}\text { Lan et } \mathrm{al}^{20} \\
(1999)\end{array}$ & $\begin{array}{l}20 \text { men } \\
56.5 \pm 7.4 \text { y/o } \\
5 \text { mon after CABG }\end{array}$ & $\begin{array}{l}\text { Tai Chi group }(\mathrm{n}=9): 1-\mathrm{yr} \text { TC } \\
\text { training, } 3.8 \text { times/wk, } 1 \mathrm{~h} \\
\text { each time, at } 48-57 \% \text { of } \mathrm{HR} \\
\text { reserve } \\
\text { Control group }(\mathrm{n}=11)\end{array}$ & $\begin{array}{l}\dot{\mathrm{v}} \mathrm{O}_{2 \text { peak }} \text { between baseline and } 1 \\
\text { yr: } \\
\mathrm{TC}: 26.2 \text { vs } 28.9 \mathrm{~mL} \cdot \mathrm{kg}^{-1} \mathrm{~min}^{-1} \\
(10.3 \%) \\
\text { Control: } 26.0 \text { vs } 25.6 \mathrm{~mL} \mathrm{~kg}^{-1} \mathrm{~min}^{-1} \\
(-1.5 \%)\end{array}$ \\
\hline $\begin{array}{l}\text { Goodman et al } 21 \\
\text { (1999) }\end{array}$ & $\begin{array}{l}31 \text { subjects } \\
53 \pm 1 \text { y/o } \\
8-10 \text { wk after CABG }\end{array}$ & $\begin{array}{l}\text { 12-wk of walking program } \\
\text { Initial intensity at } 50-60 \% \text { of } \\
\dot{\mathrm{V}} \mathrm{O}_{2 \text { peak, then increase to } 75-} \\
80 \% \text { of } \dot{\mathrm{v}} \mathrm{O}_{2 \text { peak, }} 5 \text { times } / \mathrm{wk} \text {, } \\
45-60 \text { min each session for } 3 \\
\mathrm{~m}\end{array}$ & $\begin{array}{l}\dot{\mathrm{v}} \mathrm{O}_{2 \text { peak }} \text { between baseline and } 3 \\
\text { mon: } \\
\text { CABG: } 19.0 \text { vs } 21.0 \mathrm{~mL} \mathrm{~kg}^{-1} \mathrm{~min}^{-1} \\
(10.5 \%) \\
\text { Ejection Fraction (EF): } \\
\text { At } 40 \% \text { of } \dot{\mathrm{v}} \mathrm{O}_{2 \text { peak: }} 60 \mathrm{vs} 63 \% \\
\text { At } 70 \% \text { of } \dot{\mathrm{v}} \mathrm{O}_{2 \text { peak: }} 61 \mathrm{vs} 64 \% \\
\uparrow 18 \% \text { ischemic exercise calf blood } \\
\text { flow }\end{array}$ \\
\hline $\begin{array}{l}\text { Takeyama } 22 \\
(2000)\end{array}$ & $\begin{array}{l}28 \text { patients } \\
(26 \mathrm{M} / 2 \mathrm{~F}) \\
1 \text { wk after CABG }\end{array}$ & $\begin{array}{l}\text { Exercise group }(n=13): 30 \\
\text { min bicycle exercise, twice } \\
\text { daily for } 2 \mathrm{wk} \text {, intensity at } \\
\text { ventilatory threshold (VeT) } \\
\text { Control group }(n=15) \text { : } \\
\text { walking } 200-500 \text { meters for } 2 \\
\text { wk }\end{array}$ & $\begin{array}{l}\dot{\mathrm{v}} \mathrm{O}_{2 \text { peak }} \text { between } 1 \mathrm{wk} \text { and } 3 \mathrm{wk} \text { : } \\
\text { Ex: } 13.1 \mathrm{vs} 16.1 \mathrm{~mL} \mathrm{~kg}^{-1} \mathrm{~min}^{-1} \\
(22.9 \%) \\
\text { Control:13.7 vs } 14.8 \mathrm{~mL} \mathrm{~kg}^{-1} \mathrm{~min}^{-1} \\
(8.0 \%) \\
\text { Peak CO between } 1 \mathrm{wk} \text { and } 3 \mathrm{wk}: \\
\text { Ex: } 10.6 \text { vs } 13.4 \mathrm{~L} / \mathrm{min}(26.4 \%) \\
\text { Control:11.9 vs } 12.0 \mathrm{~L} / \mathrm{min}(0.1 \%)\end{array}$ \\
\hline
\end{tabular}




\begin{tabular}{|c|c|c|c|}
\hline Study & Patients & Intervention & Outcomes \\
\hline $\begin{array}{l}\text { Adachi et } \text { al }^{23} \\
(2001)\end{array}$ & $\begin{array}{l}57 \text { patients } \\
(46 \mathrm{M} / 11 \mathrm{~F}) \\
1 \text { wk after } \mathrm{CABG}\end{array}$ & $\begin{array}{l}\text { Exercise group }(n=34): 30 \\
\text { min exercise, twice daily for } 2 \\
\text { wk, intensity at VeT } \\
\text { Control group }(n=23)\end{array}$ & $\begin{array}{l}\dot{\mathrm{v}} \mathrm{O}_{2 \text { peak }} \text { between } 1 \mathrm{wk} \text { and } 3 \mathrm{wk} \text { : } \\
\text { Ex: } 13.7 \mathrm{vs} 20.3 \mathrm{~mL} \mathrm{~kg}^{-1} \mathrm{~min}^{-1} \\
(48.2 \%) \\
\text { Control:13.7 vs } 14.3 \mathrm{~mL} \mathrm{~kg}^{-1} \mathrm{~min}^{-1} \\
(4.4 \%) \\
\uparrow \text { Ventilatory efficiency and } \\
\text { cardiac output in exercise group }\end{array}$ \\
\hline $\begin{array}{l}\text { Kodis et } \mathrm{al}^{24} \\
(2001)\end{array}$ & $\begin{array}{l}1,042 \text { patients } \\
6-8 \text { wk after CABG }\end{array}$ & $\begin{array}{l}\text { Supervised Ex }(n=713): 2 \\
\text { times per wk, at } 40-70 \% \text { of } \\
\text { functional capacity for } 6 \mathrm{~m} \\
\text { Home Ex }(n=329)\end{array}$ & $\begin{array}{l}\text { Supervised Ex group: } \uparrow 23.7 \% \\
\text { in } \dot{\mathrm{V}} \mathrm{O}_{2 \text { peak }} \text {, } \\
\uparrow \mathrm{HDL}-\mathrm{C} \text {, } \downarrow \text { LDL-C } \\
\text { Home Ex group: } \uparrow 17.2 \% \\
\text { in } \dot{\mathrm{V}} \mathrm{O}_{2 \text { peak, }} \\
\uparrow \mathrm{HDL}-\mathrm{C}\end{array}$ \\
\hline $\begin{array}{l}\text { Lan et } \mathrm{al}^{25} \\
(2002)\end{array}$ & $\begin{array}{l}20 \text { men } \\
56.5 \pm 7.4 \text { y/o } \\
2 \text { mon after CABG }\end{array}$ & $\begin{array}{l}\text { Aerobic exercise for } 3 \mathrm{~m}, 3 \\
\text { time/ wk, } 30 \mathrm{~min} \text { each } \\
\text { session, at } 51-59 \% \text { of } \\
\text { functional capacity }\end{array}$ & $\begin{array}{l}\dot{\mathrm{v}} \mathrm{O}_{2 \text { peak }} \text { between baseline and } 3 \mathrm{~m} \text { : } \\
\text { Ex: } 19.8 \text { vs } 26.3 \mathrm{~mL} \mathrm{~kg}^{-1} \mathrm{~min}^{-1} \\
(32.8 \%) \\
\dot{\mathrm{v}} \mathrm{O}_{2} \text { at VeT between baseline and } \\
3 \mathrm{~m}: \\
\text { Ex: } 11.9 \text { vs } 14.7 \mathrm{~mL} \mathrm{~kg}^{-1} \mathrm{~min}^{-1} \\
(23.5 \%)\end{array}$ \\
\hline $\begin{array}{l}\text { Chuang et } \mathrm{al}^{26} \\
(2005)\end{array}$ & $\begin{array}{l}32 \text { patients } \\
2-3 \text { mon after } C A B G\end{array}$ & $\begin{array}{l}\text { Virtual reality }(V R, n=17) \\
\text { group: simulated exercise } 2 \\
\text { times per wk, } 30 \text { min for } 3 \mathrm{~m} \\
\text { Non-VR }(n=15) \text { group: } \\
\text { exercise without simulation }\end{array}$ & $\begin{array}{l}\dot{\mathrm{V}} \mathrm{O}_{2 \text { peak }} \text { between baseline and } 3 \mathrm{~m} \text { : } \\
\text { VR: } 17.7 \text { vs } 22.5 \mathrm{~mL} \mathrm{~kg}^{-1} \mathrm{~min}^{-1} \\
(27.1 \%) \\
\text { Non-VR: } 15.1 \mathrm{vs} 16.8 \mathrm{~mL} \mathrm{~kg}^{-1} \mathrm{~min}^{-} \\
{ }^{1}(11.3 \%) \\
\uparrow \dot{\mathrm{V}} \mathrm{O}_{2} \text { at VeT in both groups }\end{array}$ \\
\hline $\begin{array}{l}\text { Sumide et } \mathrm{al}^{27} \\
(2009)\end{array}$ & $\begin{array}{l}42 \text { patients } \\
(40 \mathrm{M} / 2 \mathrm{~F}) \\
61 \pm 8 \mathrm{y} / \mathrm{o}\end{array}$ & $\begin{array}{l}\text { Aerobic and resistance } \\
\text { exercise for } 6 \mathrm{~m}, 1-2 \\
\text { time/wk, } 60 \mathrm{~min} \text { each session }\end{array}$ & $\begin{array}{l}\dot{\mathrm{v}} \mathrm{O}_{2 \text { peak }} \text { between baseline and } 6 \mathrm{~m} \text { : } \\
\text { Ex: } 15.1 \text { vs } 21.7 \mathrm{~mL} \mathrm{~kg}^{-1} \mathrm{~min}^{-1} \\
(43.7 \%) \\
\uparrow \text { Peak torque in knee extensor/ } \\
\text { flexor, and calf circumference }\end{array}$ \\
\hline $\begin{array}{l}\text { Moholdt } 28 \\
(2009)\end{array}$ & $\begin{array}{l}59 \text { patients } \\
\text { AIT: } 24 \mathrm{M} / 4 \mathrm{~F} \\
\text { MCT: } 24 \mathrm{M} / 7 \mathrm{~F}\end{array}$ & $\begin{array}{l}\text { Aerobic interval training } \\
\text { (AIT) } \\
\text { Moderate continuous } \\
\text { training (MCT) } \\
4 \text { wk in rehab center, then } \\
6-\mathrm{m} \text { home-based exercise }\end{array}$ & $\begin{array}{l}\dot{\mathrm{v}} \mathrm{O}_{2 \text { peak }} \text { between baseline and } 4 \text { wk: } \\
\text { AIT: } 27.1 \text { vs } 30.4 \mathrm{~mL} \cdot \mathrm{kg}^{-1} \mathrm{~min}^{-1} \\
(12.2 \%) \\
\text { MCT: } 26.2 \text { vs } 28.5 \mathrm{~mL} \cdot \mathrm{kg}^{-1} \mathrm{~min}^{-1} \\
(8.8 \%) \\
\dot{\mathrm{V}} \mathrm{O}_{2 \text { peak }} \text { between } 4 \mathrm{wk} \text { and } 6 \mathrm{~m}: \\
\text { AIT: } 30.4 \text { vs } 32.2 \mathrm{~mL} \cdot \mathrm{kg}^{-1} \mathrm{~min}^{-1} \\
(5.9 \%) \\
\text { MCT: } 28.5 \text { vs } 29.5 \mathrm{~mL} \mathrm{~kg}^{-1} \mathrm{~min}^{-1} \\
(3.5 \%)\end{array}$ \\
\hline $\begin{array}{l}\text { Onishi et } \mathrm{al}^{29} \\
(2009)\end{array}$ & $\begin{array}{l}32 \text { patients with } \\
\text { metabolic syndrome } \\
5-14 \text { days after CABG }\end{array}$ & $\begin{array}{l}\text { Supervised CR program for } 6 \\
\text { months, including aerobic } \\
\text { exercise }(60 \mathrm{~min}) \text { and } \\
\text { resistance training, at } \mathrm{VeT}\end{array}$ & $\begin{array}{l}\dot{\mathrm{V}} \mathrm{O}_{2 \text { peak }} \text { between baseline and } 6 \mathrm{~m}: \\
\text { Ex: } 14.2 \text { vs } 19.2 \mathrm{~mL} \mathrm{~kg}^{-1} \mathrm{~min}^{-1} \\
(35.2 \%) \\
\uparrow \text { peak torques of knee extensor } \\
(13.4 \%) \text { and knee flexors }(15.3 \%) \\
\downarrow \text { Triglyceride, LDL-C and CRP }\end{array}$ \\
\hline
\end{tabular}




\begin{tabular}{|c|c|c|c|}
\hline Study & Patients & Intervention & Outcomes \\
\hline $\begin{array}{l}\text { Bilinska et al }{ }^{30} \\
\text { (2010) }\end{array}$ & $\begin{array}{l}120 \text { Men } \\
55 \pm 6 \text { y/o } \\
3 \text { mon after CABG }\end{array}$ & $\begin{array}{l}\text { Ex group }(n=60), 6 \mathrm{wk} \\
\text { aerobic training, } 3 \text { times } / \mathrm{wk} \text {, } \\
\text { at } 70-80 \% \text { HRmax } \\
\text { Control group }(n=60)\end{array}$ & $\begin{array}{l}\text { Handgrip-induced increases in } \\
\text { HR, BP, and TPR were lower, } \\
\text { whereas SV and CO were higher } \\
\text { (by } 13 \% \text { and } 15 \% \text {, respectively) in } \\
\text { Ex group. A higher increase in NO } \\
\text { level and a lower increase in } \\
\text { noradrenaline in Ex group. }\end{array}$ \\
\hline $\begin{array}{l}\text { Shabani et al }{ }^{31} \\
(2010)\end{array}$ & 60 women & $\begin{array}{l}\text { Ex group }(n=30): 12 w k \\
\text { aerobic exercise } \\
\text { Control group }(n=30) \text { : usual } \\
\text { care }\end{array}$ & $\begin{array}{l}\text { Estimated exercise capacity and } 6 \text { min } \\
\text { walking test increased in Ex group } \\
\text { Exercise duration time } \uparrow 49.2 \% \text { and rate } \\
\text { pressure product } \uparrow 10.3 \% \text { in Ex group }\end{array}$ \\
\hline $\begin{array}{l}\text { Smith et al }{ }^{32} \\
(2011)\end{array}$ & 196 patients & $\begin{array}{l}\text { Hospital Ex group: aerobic } \\
\text { Ex } 30-50 \text { min per session, } 3 \\
\text { times/wk, at } 60-80 \% \mathrm{HR} \\
\text { reserve for } 6 \mathrm{~m} \\
\text { Home Ex group: walking in } \\
\text { home } 5 \text { times per wk }\end{array}$ & $\begin{array}{l}\text { MET between baseline and } 6 \mathrm{~m} \text { : } \\
\text { Hospital Ex: } 4.5 \text { vs } 6.2 \text { MET } \\
(37.8 \%) \\
\text { Home Ex: } 5.1 \text { vs } 6.4 \text { MET ( } 25.5 \%) \\
\text { Home-based exercise maintained } \\
\text { higher physical capacity during } 6 \text { yrs } \\
\text { follow up than hospital-based exercise }\end{array}$ \\
\hline
\end{tabular}

Table 1. Effect of Exercise Training to Functional Capacity in Patients with CABG

\subsection{Muscular strength}

Traditionally, CR program involving aerobic exercise training such as walking and cycling is emphasized. However, muscular strength is important in vocational activities and activities of daily living. Previous studies showed that moderate intensity resistance exercise might significantly increase muscular strength for cardiac patients. ${ }^{33-34}$ It is recommended that cardiac patient should start a low weight and perform one set of 10-15 repetitions using 8-10 different exercises. Some studies reported that resistance training might increase aerobic power, $15,33-34$ but other study found that resistance training can only improve muscular strength. ${ }^{19}$ Therefore, resistance training should be integrated into an aerobic exercise program. Sumide et $\mathrm{al}^{27}$ reported a 6-month aerobic exercise and resistance training program was beneficial to patients with CABG. After training, the $\dot{\mathrm{v}} \mathrm{O}_{2 \text { peak }}$ and peak lower limb torques significantly increased, and the circumferences of thigh and calf were also increased. In a recent study, Onishi et al. ${ }^{29}$ reported a 6-month aerobic and resistance training program also improved $\dot{\mathrm{v}} \mathrm{O}_{2 \text { peak }}$ and isokinetic peak torques of knee extensor and flexor in patients after CABG. It appears that a combined aerobic and resistance training program significantly increased exercise tolerance and lower limb muscle strength.

\subsection{Cardiac function}

Exercise training in healthy individuals may enhance physical capacity by both an increase in cardiac output, a central mechanism, and a widening of the arteriovenous oxygen difference, a peripheral mechanism. In patients with heart disease, previous studies suggested the enhancement of $\dot{\mathrm{v}} \mathrm{O}_{2 \text { peak }}$ only relied on peripheral adaptations, ${ }^{35-37}$ however, recent studies found the increase of $\dot{\mathrm{v}} \mathrm{O}_{2 \text { peak }}$ might be partially attributed to an elevation in cardiac output. 
Nakai et al..$^{38}$ reported the effects of exercise training on recovery of cardiac function in 115 patients after CABG. After training, stroke index increased significantly in the exercise group, but not in the usual care group. Takeyama et al22 applied a 2-week bicycle program to 13 patients with CABG, and they exercised 30-minute twice daily. The peak cardiac output increased $22.9 \%$ from $10.6 \mathrm{~L} / \mathrm{min}$ to $13.4 \mathrm{~L} / \mathrm{min}$, while the control group showed no significant improvement. Adachi et al. ${ }^{23}$ assigned 34 patients with CABG to a 2-week exercise program, and cardiac output during exercise at 20 watt and at peak exercise significantly increased in the exercise group. In a recent study, Bilinska et al ${ }^{30}$ reported that after 6 weeks of aerobic training at $70-80 \%$ of $\mathrm{HR}_{\text {peak, }}$ the stroke volume and cardiac output were higher (by $13 \%$ and $15 \%$, respectively) in trained patients compared with controls.

Goodman et al..$^{21}$ has explored central and peripheral adaptations after exercise training in 31 patients with CABG. Patients underwent 12 weeks of exercise training consisting of

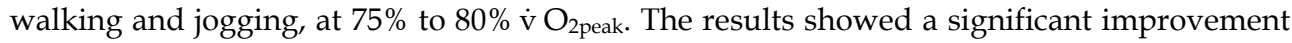
in $\dot{\mathrm{v}} \mathrm{O}_{2 \text { peak }}$ and an increase of the ejection fraction during submaximal exercise (60 $\pm 3 \%$ vs 63 $\pm 2 \%$ at $40 \% \dot{\mathrm{v}} \mathrm{O}_{2 \text { peak }} ; 61 \pm 3 \%$ vs $64 \pm 3 \%$ at $\left.70 \% \dot{\mathrm{v}} \mathrm{O}_{2 \text { peak }}\right)$. Peak ischemic exercise calf blood flow and vascular conductance were also increased. The result indicated that exercise training in patients after CABG can elicit significant improvements in functional capacity that, for the most part, are secondary to peripheral adaptations, with lesser contribution of central adaptation.

\subsection{Ventilatory efficiency}

Shortness of breath is a major complaint when ventilation is accelerated during exercise. Although exercise training may attenuate exertional dyspnea during exercise, whether exercise training improves ventilatory efficiency in patients after CABG was not clear. Adachi et al. ${ }^{23}$ reported the effects of exercise training on ventilatory response and cardiac output during exercise in patients following CABG. The minute ventilation-carbon dioxide output ( $\dot{\mathrm{v}} \mathrm{E}-\dot{\mathrm{v}} \mathrm{CO} 2$ ) slope decreased from $38.9 \pm 8.1$ to $35.1 \pm 6.7$ in the exercise group, and there was a correlation between improvement of the $\dot{v} \mathrm{E}-\dot{\mathrm{v}} \mathrm{CO} 2$ slope and peak cardiac output in the exercise group. The results showed that short-term physical training after CABG might improve ventilatory efficiency to exercise.

\subsection{Lipid profile}

Exercise training is not recommended as a sole intervention for lipid modification because the inconsistent effect on lipid and lipoprotein levels. Optimal lipid management requires dietary and pharmacologic management, in addition to CR exercise training.

Wosornu et al. ${ }^{39}$ compared the effects of 6-month aerobic or strength exercise training after CABG. Both groups showed a significant increase in physical capacity, but there were no changes in lipoprotein levels. Brügemann et al. ${ }^{40}$ randomized 137 men who underwent an coronary procedure (111 received $\mathrm{CABG}$ ) to two types of $\mathrm{CR}$, and blood lipid profile was unaffected by exercise training. However, Kodis et al. ${ }^{24}$ conducted a retrospective review of 1,042 patients with CABG and found that exercise might induce beneficial changes to lipid profile. Following 6 months of exercise training, the supervised exercise group had significant lower cholesterol and LDL-cholesterol than the home-based group. Patients in the supervised exercise group had significant improvements in triglyceride, LDL-cholesterol and HDL-cholesterol, whereas the home-based group showed improvement in HDLcholesterol only. In a recent study, Onishi et al. ${ }^{29}$ also reported CR exercise training might 
improve LDL-cholesterol and total cholesterol in CABG patients with metabolic syndrome. Additionally, metabolic scoring defined by the number of the modified Adult Treatment Panel criteria of the US National Cholesterol Education Program was significantly improved.

\subsection{Hemodynamic and neurohormonal response}

In order to measure hemodynamic and neurohormonal response to static exercise, Bilinska et $\mathrm{al}^{30}$ randomized 120 male patients to either 6 weeks of aerobic training at a $70-80 \%$ of the $\mathrm{HR}_{\text {peak }}$ or to a control group. After 3 months of training, handgrip-induced increases in HR, $\mathrm{BP}$, and total peripheral resistance were lower, whereas stroke volume and cardiac output were higher (by 13\% and 15\%, respectively) in trained patients compared with controls. Moreover, a higher increase in nitric oxide level (46\% vs $14 \%)$ and a lower increase in noradrenaline $(11 \%$ vs $20 \%)$ were observed in trained patients compared with controls. The result showed that short-term dynamic training caused significant improvement of hemodynamic and neurohormonal responses to static exercise.

\subsection{Quality of life}

Heather et al. ${ }^{40}$ recruited 249 patients on a waiting list for elective CABG and randomized them into an intervention group and a control group. During the waiting period, the training group exercised twice per week, with education and reinforcement. After surgery, both groups participated in a CR program. Quality of life was measured by short-form 36 (SF-36) questionnaire during the waiting period, and patients in the intervention group showed a significant increase in the scores of physical role, physical functioning, bodily pain and composite physical summary score. The intervention group displayed better quality of life than the control group, but mainly in physical component, and the improvement continued up to 6 months after surgery.

In a recent study, Brügemann et al.41 randomized 137 men to one of two types of CR: physical training plus information ('Fit' program) during 6 weeks or comprehensive CR which, on top of the Fit-program, included weekly psycho-education sessions and relaxation therapy ('Fit-Plus' program) for 8 weeks. The results showed that quality of life improved in both treatment groups in the course of time up to 9 months after training, and there was no difference between the two types of CR.

\subsection{Graft patency, cardiac events and readmission}

Nakai et al. ${ }^{38}$ reported the effects of exercise training on recovery of cardiac function and graft patency in 115 patients after CABG. The patients were divided into Group I ( $\mathrm{n}=60)$ with and Group II $(n=55)$ without a CR program. The rate of graft patency was $98 \%$ in Group I and $80 \%$ in Group II. After training, the exercise stroke index increased significantly in Group I, but not in Group II. The result suggested that physical exercise training should be started as early as possible after CABG to improve graft patency and recovery of cardiac function.

Perk J et al.42 reported in a study including 49 CABG patients participating in a comprehensive CR program and 98 matched patients receiving standard care. During the first year after CABG, fewer study group patients were readmitted to hospital (14\% vs 32\%) and on fewer occasions (1.1 vs 2.9). There were no differences in the rates of returning to work $(59 \%$ vs $64 \%)$. In a long-term follow-up, the study group patients rated their physical 
work capacity higher, and more patients had continued with regular physical training $(66 \%$ vs $46 \%$ ). Hedbäck et al. ${ }^{43}$ reported in a study included 49 patients who underwent CABG and were offered a CR program consisting of education in risk-factor control and a physical training program. After 10 years of follow up, the study group had lower cardiac events than in the control group (18.4\% versus $34.7 \%)$. The number of readmissions to hospital (2.1 versus 3.5 per patient) and length of admissions (11 versus 26 days per patient) were significantly lower in the study group. The result proved that a comprehensive CR program after CABG will improve long-term prognosis and reduce the need for hospital care.

In a recent study, Plüss et al. ${ }^{44}$ randomized 224 patients with acute myocardial infarction or undergoing CABG to expanded CR (a one-year stress management program, increased physical training, staying at a 'patient hotel' for five days after the event, and cooking sessions), or to standard CR. The number of cardiovascular events was reduced in the expanded CR group compared with the standard CR (47.7\% versus $60.2 \%)$. This was mainly because of a reduction of myocardial infarctions in the expanded CR group. Days at hospital for cardiovascular reasons were significantly reduced in patients who received expanded CR (median 6 days) compared with standard CR (median 10 days). The result showed that expanded CR reduces cardiovascular morbidity and days at hospital.

\section{Tai Chi Chuan training}

Tai Chi Chuan (TCC) is a popular Chinese conditioning exercise. The exercise intensity of TCC was low to moderate, depends on its training style, posture and duration. Participants can choose to perform a complete set of TC or selected movements according to their needs. Previous research substantiates that TC enhances aerobic capacity, muscular strength, endothelial function and psychological well-being. In addition, TC benefits to some cardiovascular risk factors, such as hypertension and dyslipidemia. Recent studies also prove that TC is safe and effective for patients with myocardial infarction, bypass surgery and heart failure. Channer et al. ${ }^{45}$ reported that the application of TCC for patients with acute myocardial infarction was safe and showed benefits to blood pressure. There are several reasons to recommend TCC as an exercise program for patients with CABG. First, TCC did not need special facility or expensive equipment. Second, TCC is effective for enhancing health fitness and improving cardiovascular risk factors. Third, TCC is low cost and low technology, and can be easily implemented in the community. We have applied a 12-month TCC program to patients with CABG as a phase III cardiac rehabilitation program. ${ }^{25}$ After training, the TCC group showed an increase of $10.3 \%$ in $\dot{\mathrm{v}} \mathrm{O}_{2 \text { peak }}$ and $11.9 \%$ in peak work rate. Therefore, TC may be prescribed as an alternative exercise program for selected patients with CABG.

\section{Off-pump and minimally invasive CABG}

Off-pump coronary artery bypass grafting (OPCAB) uses fewer resources than conventional $\mathrm{CABG}$ with cardiopulmonary bypass (CABG-CPB). It was estimated that $20 \%$ of CABG operations using $\mathrm{OPCAB}$ in western countries, but over $60 \%$ of isolated $\mathrm{CABG}$ have been performed in Japan using the OPCAB technique. OPCAB grafting reduces the risk of postoperative morbidity, length of hospital stay than conventional surgery with cardiopulmonary bypass. 
In a recent study, Angelini et al. ${ }^{46}$ reported the graft patency 6-8 years after CABG was similar between OPCAB and CABG-CPB, and the major adverse cardiovascular events or death showed no difference between the two groups. The health-related quality of life was similar between the OPCAB and CABG-CPB groups. In addition, with increasing expertise and technology, minimally invasive and robotic techniques have been developed to enhance post-operative recovery and patient satisfaction. ${ }^{47}$ However, there is no study compare the effect of exercise training on conventional CABG and those new techniques, further study is needed to evaluate the difference between conventional and new surgical techniques to the outcomes in patients with CABG.

\section{Conclusion}

Short-term exercise training for patients with CABG showed benefits to cardiorespiratory function, muscular strength, metabolic profile, cardiac function, ventilatory efficiency, hemodynamic function and quality of life. Additionally, exercise training may improve graft patency, reduce cardiac events and readmission rate. Thus, CR exercise training is an important intervention and should be recommended to most of the patients after CABG.

\section{References}

[1] Hamm CW, Reimers J, Ischinger T, et al. A randomized study of coronary angioplasty compared with bypass surgery in patients with symptomatic multivessel coronary disease. N Engl J Med 1994;331:1037-43.

[2] Bourassa MG, Knatterud GL, Pepine CJ, et al. Asymptomatic Cardiac Ischemia Pilot (ACIP) Study. Improvement of cardiac ischemia at 1 year after PTCA and CABG. Circulation 1995;92:II1-II7.

[3] Holmes DR, Vlietstra RE, Mock MB. Employment and recreation patterns in patients treated by percutaneous transluminal coronary angioplasty: a multicenter study. Am J Cardiol 2000;52:710-3.

[4] Holmes DR, Jr., Van Raden MJ, Reeder GS, et al. Return to work after coronary angioplasty: a report from the National Heart, Lung, and Blood Institute Percutaneous Transluminal Coronary Angioplasty Registry. Am J Cardiol 1984;53:48C-51C.

[5] Raft D, McKee DC, Popio KA, et al. Life adaptation after percutaneous transluminal coronary angioplasty and coronary artery bypass grafting. Am J Cardiol 1985;56:395-8.

[6] Popma JJ, Califf RM, Topol EJ. Clinical trials of restenosis after coronary angioplasty. Circulation 1991;84:1426-36.

[7] Five-year clinical and functional outcome comparing bypass surgery and angioplasty in patients with multivessel coronary disease. A multicenter randomized trial. Writing Group for the Bypass Angioplasty Revascularization Investigation (BARI) Investigators. JAMA 1997;277:715-21.

[8] King SB, III, Lembo NJ, Weintraub WS, et al. A randomized trial comparing coronary angioplasty with coronary bypass surgery. Emory Angioplasty versus Surgery Trial (EAST) N Engl J Med 1994;331:1044-50.

[9] Hlatky MA, Boothroyd DB, Bravata DM, et al. Coronary artery bypass surgery compared with percutaneous coronary interventions for multivessel disease: a 
collaborative analysis of individual patient data from ten randomised trials. Lancet 2009; 373: 1190-97

[10] Serruys PW, Morice, MC, Kappetein AP, et al. Percutaneous coronary intervention versus coronary artery bypass grafting for severe coronary artery disease. N Engl J Med 2009; 360: 961-72.

[11] Hannan EL, Racz, MJ, Gary Walford G, et al. Long-term outcomes of coronary artery bypass grafting versus stent implantation. N Engl J Med 2005;352:2174-83.

[12] Whitlow PL, Dimas AP, Bashore TM, et al. Relationship of extent of revascularization with angina at one year in the Bypass Angioplasty Revascularization Investigation (BARI). J Am Coll Cardiol 1999;34:1750-9.

[13] American College of Sports Medicine: Guidelines for Exercise Testing and Exercise Prescription. 8th ed. Philadelphia: Lea \& Febiger, 2010.

[14] Kavanagh T, Mertens DJ, Hamm LF, et al. Prediction of long-term prognosis in 12,169 men referred for cardiac rehabilitation. Circulation 2002;106:666-71.

[15] Haennel RG, Quinney AH, Kappagoda CT. Effects of hydraulic circuit training following coronary artery bypass surgery. Med Sci Sports Exerc 1991;23:158-65.

[16] Engblom E, Hietanen EK, Hämäläinen $H$, et al. Exercise habits and physical performance during comprehensive rehabilitation after coronary artery bypass surgery. Eur Heart J 1992;13:1053-9.

[17] Dubach P, Myers J, Dziekan G, et al. Effect of residential cardiac rehabilitation following bypass surgery. Chest 1995;108:134-9.

[18] Daida H, Squires RW, Allison TG, et al. Sequential assessment of exercise tolerance in heart transplantation compared with coronary artery bypass surgery after phase II cardiac rehabilitation. Am J Cardiol 1996; 77:696-700.

[19] Mariorana AJ, Briffa TG, Goodman C, et al. A controlled trial of circuit weight training on aerobic capacity and myocardial oxygen demand in men after coronary artery bypass surgery. J cardiopulm Rehabil 1997;17:239-47.

[20] Lan C, Chen SY, Lai JS, et al. The effect of Tai Chi on cardiorespiratory function in patients with coronary artery bypass surgery. Med Sci Sports Exerc 1999;31:634-8.

[21] Goodman JM, Pallandi DV, Reading JR, et al. Central and peripheral adaptations after 12 weeks of exercise training in post-coronary artery bypass surgery patients. J Cardiopulm Rehabil 1999;19:144-50.

[22] Takeyama J, Itoh $\mathrm{H}$, Kato $\mathrm{M}$, et al. Effect of physical training on the recovery of the autonomic nervous activity during exercise after coronary artery bypass grafting. Jpn Circ J 2000; 64:809-13.

[23] Adachi H, Itoh H, Sakurai S, et al. Short-term physical training improves ventilatory response to exercise after coronary arterial bypass surgery. Jpn Circ J 2001; 65: 41923.

[24] Kodis J, Smith KM, Arthur HM, et al. Changes in exercise capacity and lipid after clinic versus home-based aerobic training in coronary artery bypass graft surgery patients. J Cardiopulm Rehabil 2001;21:31-6.

[25] Lan C, Chen SY, Hsu CJ, et al. Improvement of cardiorespiratory function in patients with percutaneous transluminal coronary angioplasty or coronary artery bypass grafting during outpatient rehabilitation. Am J Phys Med Rehabil 2002;81:336-41.

[26] Chuang TY, Sung WH, Lin CY. Application of a virtual reality-enhanced exercise protocol in patients after coronary bypass. Arch Phys Med Rehabil 2005;86:1929-32. 
[27] Sumide T, Shimada K, Ohmura H, et al. Relationship between exercise tolerance and muscle strength following cardiac rehabilitation: comparison of patients after cardiac surgery and patients with myocardial infarction. J Cardiol 2009; 54: 273-81.

[28] Moholdt TT, Amundsen BH, Rustad LA, et al. Aerobic interval training versus continuous moderate exercise after coronary artery bypass surgery: a randomized study of cardiovascular effects and quality of life. Am Heart J 2009;158:1031-7

[29] Onishi T, Shimada K, Sunayama S, et al. Effects of cardiac rehabilitation in patients with metabolic syndrome after coronary artery bypass grafting. J Cardiol 2009;53:381-7.

[30] Bilinska M, Kosydar-Piechna M, Gasiorowska A, et al. Influence of dynamic training on hemodynamic, neurohormonal responses to static exercise and on inflammatory markers in patients after coronary artery bypass grafting. Circ J 2010;74:2598-604.

[31] Shabani R, Gaeini AA, Nikoo MR, et al. Effect of cardiac rehabilitation program on exercise capacity in women undergoing coronary artery bypass graft in hamadaniran. Int J Prev Med 2010;1:247-51.

[32] Smith KM, McKelvie RS, Thorpe KE, et al. Six-year follow-up of a randomized controlled trial examining hospital versus home-based exercise training after coronary artery bypass graft surgery. Heart 2011;97:1169-74.

[33] Kelemen MH, Stewart KJ, Gillilan RE, et al. Circuit weight training in cardiac patients. J Am Coll Cardiol 1986;7:38-42.

[34] McCartney N, McKelvie RS, Haslam DR, et al. Usefulness of weightlifting training in improving strength and maximal power output in coronary artery disease. Am J Cardiol 1991;67:939-45.

[35] Hagberg JM, Eshani AA, Holloszy JO. Effect of 12 months of intense exercise training on stroke volume in patients with coronary artery disease. Circulation 1983; 1194-9.

[36] Ehsani AA, Biello DR, Schultz J, et al. Improvement of left ventricular contractile function by exercise training in patients with coronary artery disease. Circulation 1986; 64: 1116-24.

[37] Laslett LJ, Paumer L, Ammsterdam EA. Increases in myocardial oxygen consumption indexes by exercise training at onset of ischemia in patients with coronary artery disease. Circulation 1985; 72: 958-62.

[38] Nakai Y, Kataoka Y, Bando M, et al. Effects of physical exercise training on cardiac function and graft patency after coronary artery bypass grafting. J Thorac Cardiovasc Surg 1987;93:65-72.

[39] Wosornu D, Bedford D, Ballantyne D. A comparison of the effects of strength and aerobic exercise training on exercise capacity and lipids after coronary artery bypass surgery. Eur Heart J 1996;17:854-63.

[40] Heather AM, Daniels C, Mckelvie R, et al. Effect of a preoperative intervention on preoperative and postoperative outcomes in low-risk patients awaiting elective coronary artery bypass graft surgery. Ann Intern Med 2000;133:253-62.

[41] Brügemann J, Poels BJ, Oosterwijk MH et al. A randomized controlled trial of cardiac rehabilitation after revascularisation. Int J Cardiol. 2007;119:59-64.

[42] Perk J, Hedbäck B, Engvall J. Effects of cardiac rehabilitation after coronary artery bypass grafting on readmissions, return to work, and physical fitness. A casecontrol study. Scand J Soc Med 1990;18:45-51. 
[43] Hedbäck B, Perk J, Hörnblad M, et al. Cardiac rehabilitation after coronary artery bypass surgery: 10-year results on mortality, morbidity and readmissions to hospital. J Cardiovasc Risk 2001;8:153-8.

[44] Plüss CE, Billing E, Held C, et al. Long-term effects of an expanded cardiac rehabilitation programme after myocardial infarction or coronary artery bypass surgery: a five-year follow-up of a randomized controlled study. Clin Rehabil 2011;25:79-87.

[45] Channer KS, Barrow D, Barrow R, et al. Changes in hemodynamic parameters following Tai Chi Chuan and aerobic exercise in patients recovering from acute myocardial infarction. Postgrad Med J 1996;72:349-51.

[46] Angelini GD, Culliford L, Smith DK, et el. Effects of on- and off-pump coronary artery surgery on graft patency, survival, and health-related quality of life: long-term follow-up of 2 randomized controlled trials. J Thorac Cardiovasc Surg 2009;137:295303.

[47] Atluri P, Kozin ED, Hiesinger W, et al. Off-pump, minimally invasive and robotic coronary revascularization yield improved outcomes over traditional on-pump CABG. Int J Med Robot 2009;5:1-12. 


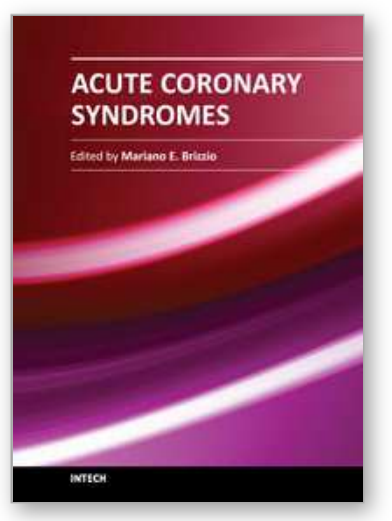

\author{
Acute Coronary Syndromes \\ Edited by Dr. Mariano Brizzio
}

ISBN 978-953-307-827-4

Hard cover, 214 pages

Publisher InTech

Published online 24, February, 2012

Published in print edition February, 2012

This book has been written with the intention of providing an up-to-the minute review of acute coronary syndromes. Atherosclerotic coronary disease is still a leading cause of death within developed countries and not surprisingly, is significantly rising in others. Over the past decade the treatment of these syndromes has changed dramatically. The introduction of novel therapies has impacted the outcomes and surviving rates in such a way that the medical community need to be up to date almost on a "daily bases". It is hoped that this book will provide a timely update on acute coronary syndromes and prove to be an invaluable resource for practitioners seeking new and innovative ways to deliver the best possible care to their patients.

\title{
How to reference
}

In order to correctly reference this scholarly work, feel free to copy and paste the following:

Ching Lan, Ssu-Yuan Chen and Jin-Shin Lai (2012). Exercise Training for Patients After Coronary Artery Bypass Grafting Surgery, Acute Coronary Syndromes, Dr. Mariano Brizzio (Ed.), ISBN: 978-953-307-827-4, InTech, Available from: http://www.intechopen.com/books/acute-coronary-syndromes/exercise-training-forpatients-with-coronary-artery-bypass-graft

\section{INTECH}

open science | open minds

\section{InTech Europe}

University Campus STeP Ri

Slavka Krautzeka 83/A

51000 Rijeka, Croatia

Phone: +385 (51) 770447

Fax: +385 (51) 686166

www.intechopen.com

\section{InTech China}

Unit 405, Office Block, Hotel Equatorial Shanghai

No.65, Yan An Road (West), Shanghai, 200040, China

中国上海市延安西路65号上海国际贵都大饭店办公楼 405 单元

Phone: $+86-21-62489820$

Fax: $+86-21-62489821$ 
(C) 2012 The Author(s). Licensee IntechOpen. This is an open access article distributed under the terms of the Creative Commons Attribution 3.0 License, which permits unrestricted use, distribution, and reproduction in any medium, provided the original work is properly cited. 